\title{
Zeolite-Rich Composite Materials for Environmental Remediation: Arsenic Removal from Water
}

\author{
Bruno de Gennaro ${ }^{1, *(\mathbb{D}}$, Paolo Aprea ${ }^{1}\left(\mathbb{D}\right.$, Barbara Liguori ${ }^{1} \mathbb{D}$, Barbara Galzerano ${ }^{1,2}{ }^{\mathbb{D}}$, \\ Antonio Peluso 1,3 and Domenico Caputo 1,3 (D) \\ 1 ACLabs-Applied Chemistry Labs, Department of Chemical, Materials and Industrial Production \\ Engineering, University of Naples Federico II, P.le V. Tecchio 80, 80125 Naples, Italy; \\ paolo.aprea@unina.it (P.A.); barbara.liguori@unina.it (B.L.); barbara.galzerano@unina.it (B.G.); \\ antonio.peluso2@unina.it (A.P.); domenico.caputo@unina.it (D.C.) \\ 2 Institute of Polymers, Composite and Biomaterials, National Research Council, P.le E. Fermi 1, \\ 80055 Portici (NA), Italy \\ 3 CeSMA-Centro di Servizi Metrologici e Tecnologici Avanzati, University of Naples Federico II, \\ Corso N. Protopisani, 80146 Naples, Italy \\ * Correspondence: bruno.degennaro@unina.it
}

Received: 7 September 2020; Accepted: 30 September 2020; Published: 3 October 2020 updates

\begin{abstract}
Natural zeolites are used as adsorbents in purification processes due to their cation-exchange ability and molecular sieve properties. Surface modified natural zeolites (SMNZs), produced by attaching cationic organic surfactants to the external surface, can simultaneously act as ionic exchangers and organic molecule adsorbents. In this paper, SMNZs were produced and investigated as adsorbents for $\mathrm{As}(\mathrm{V})$ removal from wastewater: two natural zeolites, clinoptilolite and phillipsite, were modified using HDTMA-Br and HDTMA-Cl as surfactants. The obtained samples were then characterized under static and dynamic conditions. Results showed that $\mathrm{As}(\mathrm{V})$ removal follows a pseudo-second order kinetic, with fast adsorption rates: every sample reached $100 \%$ removal in $2 \mathrm{~h}$, while equilibrium data showed a Langmuir-like behavior, with a greater anion uptake by the HDTMA-Br modified SMNZs due to the formation of a compact and complete micellar structure. Finally, fixed-bed tests were performed to characterize the samples under dynamic conditions assessing the effect of severe operating parameters on the dynamic exchange capacity, selectivity and efficiency of the process. The obtained results demonstrate a good ability of the tested materials to adsorb $\mathrm{As}(\mathrm{V})$ from wastewater, confirming the effectiveness of the proposed surface modification technique in expanding the possibility of using natural zeolites in these processes.
\end{abstract}

Keywords: surface modified natural zeolites (SMNZs); HDTMA-Br/Cl; anion exchange; arsenic removal; mathematical modeling

\section{Introduction}

Arsenic is considered as one of the most toxic pollutants due to its mutagenic and carcinogenic effect on human beings. The continuous industrialization of developing countries will probably lead to an increase in arsenic release in the environment, which will cause potentially serious problems throughout the world [1]. The presence of arsenic in water is due to the dissolution of minerals from subterranean strata or from anthropogenic activities such as the leaching of manmade arsenic compounds deriving from smelting of metal ores, agricultural pesticides, desiccants and wood preservatives production [2]. In particular, the presence of arsenic in water supplies has been indicated as responsible for arsenical dermatitis, enlargement of liver, neurological effects, heart disease and several forms of cancer [3]. 
Arsenic is sensitive to mobilization at $\mathrm{pH}$ values typical of natural waters ( $\mathrm{pH}$ 6.5-8.5) under both oxidizing and reducing conditions; while it can occur in the environment in several oxidation states $(-3,0,+3$ and +5$)$, in natural waters it is mostly found in inorganic forms as oxyanions of trivalent arsenite $[\mathrm{As}(\mathrm{III})]$ or pentavalent arsenate $[\mathrm{As}(\mathrm{V})]$ [4]. According to the EPA (Environmental Protection Agency) the acceptable level of As in drinking water is fixed at $0.010 \mathrm{mg} / \mathrm{L}$ [5].

The oxidation-reduction conditions affect the speciation of arsenic: in oxygen-rich environments, where aerobic conditions persist, arsenate $[\mathrm{As}(\mathrm{V})]$ is prevalent and exists as a monovalent $\left(\mathrm{H}_{2} \mathrm{AsO}_{4}{ }^{-}\right)$ or divalent $\left(\mathrm{HAsO}_{4}{ }^{2-}\right)$ anion, whereas arsenite [As(III)] exists as acid $\left(\mathrm{H}_{3} \mathrm{AsO}_{3}\right)$ and anionic $\left(\mathrm{H}_{2} \mathrm{AsO}_{3}{ }^{-}\right)$ species in a moderately reducing environment, where anoxic conditions persist [6,7]. Between the two forms, $\mathrm{As}(\mathrm{III})$ is more "mobile" and at the same time much more toxic than $\mathrm{As}(\mathrm{V})$ which is easily fixed onto soil particles [8].

Several techniques have been developed to remove arsenic from water: coagulation, reverse osmosis, adsorption and anion exchange processes are some of the commonly used $[9,10]$. Due to both their low cost and a relatively operational ease, there is now a raising interest on sorption methods that seem to be the most promising way to remove arsenic from water sources [11]. Several materials have already been studied for the adsorption of arsenic from water, including metal-loaded coral limestone [12,13] hematite and feldspar, sandy soils [14], activated carbon [15-18], activated alumina [19,20], lanthanum-impregnated silica gel [21], hydrous zirconium oxide [22] and hydrous iron oxide [23] and zero valent iron [24,25]. Ohki et al. [13] found an adsorption capability of $150 \mu \mathrm{g} / \mathrm{g}$ $\mathrm{As}(\mathrm{V})$ on coral limestone, while $\mathrm{Xu}$ et al. [14] investigated the adsorption capacity of drinking water treatment solids (DWTS) in As(V) removal processes: at its best, DWTS adsorption capability was found to be $170 \mathrm{mg} / \mathrm{g}$, although heavily affected by $\mathrm{pH}$ conditions.

Recently, activated carbons (both commercial and synthetized at lab scale) were heavily tested to remove arsenic from water sources: Pattanayak et al. [26] found that char carbon can remove $89 \mathrm{mg} / \mathrm{g}$ of $\mathrm{As}(\mathrm{III})$ and $34.46 \mathrm{mg} / \mathrm{g}$ of $\mathrm{As}(\mathrm{V})$ from water under strong acidic conditions $(\mathrm{pH}=2)$. Coconut husk carbon showed also high performances: this material was tested by Manju et al. [27] on arsenic removal from industrial wastewater, and they found that it was able to adsorb $146.3 \mathrm{mg} / \mathrm{g}$ of As(III).

In recent years, other materials with anion exchange properties gained attention as potentially good candidates to remove arsenic from water sources, since their anion exchange capacity can be useful in the removal process. Among the possible candidates, zeolites seem to be quite promising. Zeolites are inorganic cation-exchangers of natural and synthetic origin. Many deposits of natural zeolites of sedimentary origin, commonly referred to as zeolitc tuffs, are diffused all over the globe [28]. The documented characteristics of affinity of natural zeolites toward several heavy metal cations and their modest cost, due to the wide availability, make the ion-exchange an advantageous procedure, suitable for pollution removal $[29,30]$.

In order to make a zeolite able to exchange anions, the cations found on the raw zeolite surface can be replaced by long chained cationic surfactants such as hexadecyltrimethylammonium (HDTMA), by an ion exchange process; due to the large dimensions of such molecules, the exchange takes place on the zeolite grain surface only. If the formation of a double layer (micelle formation) of organic molecules is induced by ion-exchange and tail-tail interaction among the surfactant hydrophobic chains, the charge on the zeolite surface changes from negative to positive [31,32]. The positive surface charge provides sites for the exchange of anions such as chromate and arsenate. In this way, surfactant-modified zeolites (SMZ) can act as both cation and anion inorganic exchangers.

Figure 1 shows the mechanism that leads to the formation first of the monolayer by surface ion exchange and later of the patchy or complete bilayers by interaction of the hydrophobic tails of the surfactant molecules. 


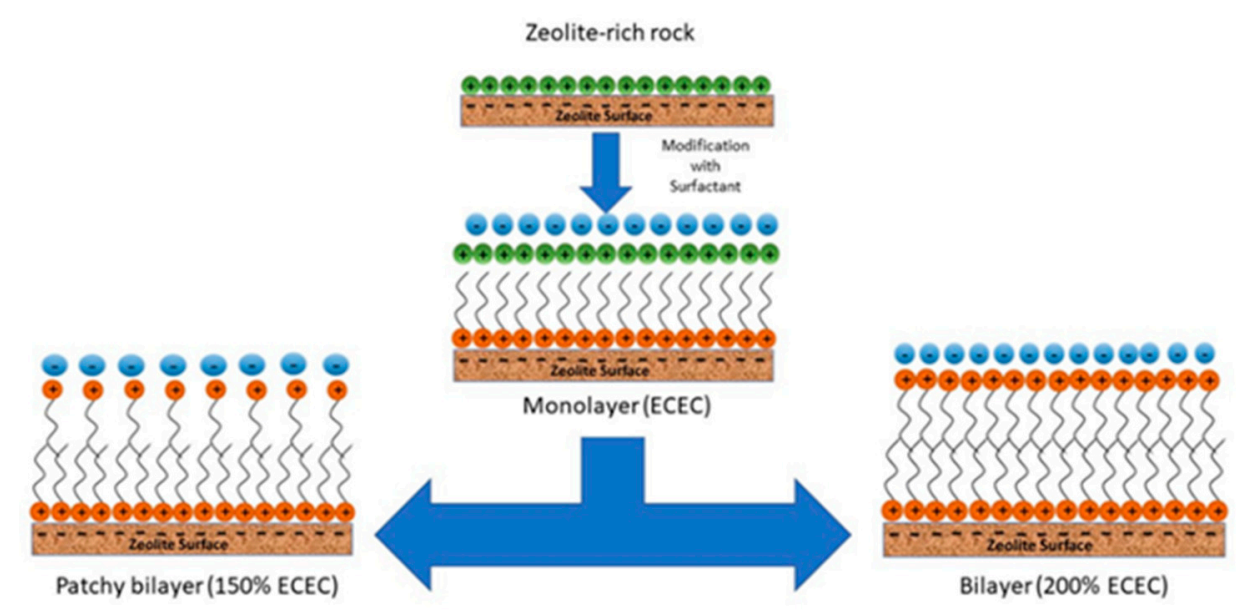

Figure 1. Scheme of the zeolite surface modification: monolayer formation by ion exchange and formation of the bilayer (patchy or complete) by interaction between the surfactant hydrophobic tails.

Recently, natural zeolites, particularly clinoptilolite, modified with cationic surfactant, were used to remove different types of contaminants from water: nitrates [9], chromates [33,34], cesium, lead, zinc [34], perchloroethylene [35], sulfates [36], NSAIDs [37] and antibiotics [38].

Regarding the $\mathrm{As}(\mathrm{V})$ removal, some researchers examined the behavior of both HDTMA-modified, mordenite and clinoptilolite rich tuff, in the elimination of this polluting oxyanion from aqueous solutions [39]. The authors, although basing on the results of thermodynamic runs, showed that the two samples removed arsenic with different kinetics. Moreover, in agreement with an earlier study, they established that surfactant surface coverage plays a key role in sorption; in particular, when the HDTMA loading level on zeolite exceeds monolayer coverage, a substantial increase in arsenate sorption capacity could be attained.

Li et al. [40] also carried out a comparison between a surface-modified clinoptilolite and kaolinite minerals in the arsenic removal process. For this aim, the authors performed some equilibrium runs by contacting the modified systems with arsenate or arsenite solution at $0.1-2.0 \mathrm{mM}$ in tubes, under continuous stirring for $24 \mathrm{~h}$. The outcomes exhibited a notable increase in arsenate sorption capacity when the loading level of HDTMA on zeolite and kaolinite surfaces overrun monolayer coverage up to the bilayer formation (200\% of the ECEC).

Furthermore, Mendoza-Barrón et al. [41] emphasized the effect of $\mathrm{pH}$ on the As(V) removal process through a clinoptilolite sample modified with HDTMA-Br. In aforementioned work, after the surface modification of a clinoptilolite-rich rock to improve its anionic capacity, adsorption equilibrium runs of $\mathrm{As}(\mathrm{V})$ from water solutions were carried out. Based on the results, it was proved that the affinity of the modified zeolite for $\mathrm{As}(\mathrm{V})$ was extremely dependent on the form of arsenic species implicated in the solution at different $\mathrm{pH}$. The adsorption capacity increased with solution $\mathrm{pH}$, from $\mathrm{pH} 5$ to $\mathrm{pH}$ 7. This implied that, among the different As forms, the affinity of the $\mathrm{HAsO}_{4}{ }^{2-}$ toward the $\mathrm{SMZ}$ was higher than that of the $\mathrm{H}_{2} \mathrm{AsO}_{4}{ }^{-}$.

However, most of the published research has mainly considered the study of the As removal mechanism through the execution of thermodynamic test. On the contrary, few are the data concerning kinetic analysis in batch or in dynamic conditions to better simulate the effects and the feasibility of a more realistic As abatement process such as the pump and treat column. Moreover, clinoptilolite was the main zeolite sample investigated.

On this basis, the aim of the present research is to verify a possible use of two natural zeolites-a phillipsite-rich tuff (PHI) from Marano (Naples, Italy) and a clinoptilolite-rich tuff (CLI) from Eskişehir (Turkey) — modified by exchange with cationic surfactants HDTMA bromide and HDTMA chloride, as alternative adsorbents for removing arsenate from water solutions. 
The ability of these surfactant-modified natural zeolites (SMNZs) to remove As(V) from water was studied at first by kinetic and thermodynamic experiments in batch, to verify the efficiency and the selectivity of modified zeolites towards $\mathrm{As}(\mathrm{V})$. Later, dynamic runs were performed by eluting fixed-bed columns containing the selected SMNZs with $\mathrm{As}(\mathrm{V})$ solutions to verify their ability to remove the anion under more realistic conditions.

\section{Materials and Methods}

\subsection{Materials Characterization}

\subsubsection{Mineralogical Characterization}

A phillipsite-rich tuff (PHI) from Marano (Naples, Italy) and a clinoptilolite-rich tuff (CLI) from Eskişehir (Turkey), both commercialized by Italiana Zeoliti-CBC Group, Pigneto (MO), were selected for the present research. Samples were crushed and sieved to select a particle size of 35-50 mesh. The two tuffs were then subjected to mineralogical and chemical characterization. In brief, samples were investigated by qualitative X-Ray Powder Diffraction (XRPD), using a PANalytical X'Pert Pro diffractometer equipped with a RTMS detector ( $X^{\prime}$ Celerator), under the following operating conditions: $\mathrm{CuK} \alpha$ radiation, $40 \mathrm{kV}, 40 \mathrm{~mA}$, scanning range from 3 to $80^{\circ} 2 \Theta$, equivalent step size $0.0179^{\circ} 2 \Theta$, equivalent counting time $120 \mathrm{~s}$ per step. Quantitative mineralogical characterization was carried out using the RIR/Rietveld method with internal standard, by means of TOPAS 4.2 software (BRUKER AXS Company) [42].

The chemical composition of the two tuffs was evaluated by digesting, under microwave-induced heating (Perkin Elmer Multiwave 3000 oven), a weighed amount of sample in a mixed $\mathrm{HCl}$ and $\mathrm{HNO}_{3}$ and $\mathrm{HF}$ solution. After the addition of $\mathrm{H}_{3} \mathrm{BO}_{3}$ to attain fluoride complexation, the resulting solution was analyzed by ICP atomic emission spectrophotometry, using a Perkin Elmer Optima 2100 DV apparatus [42]. Loss on ignition (L.O.I.) was measured by thermogravimetry (Netzsch STA 409).

\subsubsection{Ion-Exchange Characterization}

The Cation Exchange Capacity (CEC), which indicates the maximum amount of cations (expressed as meq) exchangeable by $1 \mathrm{~g}$ of tuff, was assessed using the Cross-Exchange Method (CEM) [43], which permits the estimation of the amounts of exchangeable cations removed by elution from the specimen, using two different solutions: one with high content of $\mathrm{K}^{+}$, for which most natural zeolites exhibit a valuable selectivity; the other rich in $\mathrm{Na}^{+}$, for which natural zeolites are generally weakly selective. Subsequently, two $0.5 \mathrm{~g}$ zeolite samples, placed on Gooch filters, were percolated drop by drop, at about $60^{\circ} \mathrm{C}$, up to exhaustion by $1 \mathrm{M} \mathrm{NaCl}$ (CAS: 7647-14-5; $\mathrm{M}=58.44 \mathrm{~g} / \mathrm{mol}$; Sigma Aldrich; assay: $>99.0 \%$ ) or $\mathrm{KCl}$ (CAS: 7447-40-7; $\mathrm{M}=74.55 \mathrm{~g} / \mathrm{mol}$; Sigma Aldrich; assay: $>99.0 \%$ ) solutions (purity of the chemicals: $99.5 \%$ ). The monocationic $\left(\mathrm{Na}^{+}\right.$or $\mathrm{K}^{+}$) sample forms, after suitable washing, were then cross-exchanged in the equal way as aforementioned with $\mathrm{K}^{+}$or $\mathrm{Na}^{+}$solutions, respectively. The CEC was determined after the cationic content evaluation via ICP-OES.

In addition to the CEC evaluation, the External Cationic Exchange Capacity (ECEC)-i.e., the maximum amount of cations exchangeable on the zeolite surface-was determined by contacting $0.5 \mathrm{~g}$ of the starting material and $50 \mathrm{~mL}$ of surfactant solution $(100 \mathrm{mM}$ Hexadecyltrimethylammonium bromide, HDTMA-Br (CAS: 57-09-0; $M=364.45 \mathrm{~g} / \mathrm{mol}$; Sigma Aldrich; assay: $>97.0 \%$ )) under continuous stirring and at room temperature, replacing the total volume of the exhausted solution with a fresh one every $12 \mathrm{~h}$ [32]. The obtained supernatants were analyzed for the exchanged cations ( $\mathrm{Na}, \mathrm{K}, \mathrm{Ca}$ and $\mathrm{Mg}$ ) using ICP-OES.

The ECEC evaluation was performed only with HDTMA-Br since previous experience [42] demonstrated, in the evaluation of the ECEC of clinoptilolite, phillipsite and chabazite samples that the influence of the selected surfactant (HDTMA-Br, HDTMA-Cl, $\mathrm{CP}-\mathrm{Cl}$ and $\mathrm{BC}-\mathrm{Cl}$ ) on the results was negligible. 


\subsubsection{Functionalization of Natural Zeolite-Rich Tuffs}

Samples of surfactant modified natural zeolite (SMNZ) were prepared using HDTMA-Br (CAS: 57-09-0; $\mathrm{M}=320.00 \mathrm{~g} / \mathrm{mol}$; Sigma Aldrich; assay: >98.0\%) and HDTMA-Cl (CAS: 112-02-7; $\mathrm{M}=364.45 \mathrm{~g} / \mathrm{mol}$; Sigma Aldrich; assay: $>97.0 \%$ ) as surfactants. SMNZs were obtained under dynamic conditions by circulating a $20 \mathrm{mM}$ surfactant solution through packed beds of PHI or CLI zeolite until the surfactant concentration in the effluent became constant. After that, solid and liquid phases were separated; then, the SMNZs were washed with distilled water to remove any excess of surfactant and dried at room temperature. In total, four samples were obtained, indicated as $\mathrm{PHI}-\mathrm{Br}$, $\mathrm{PHI}-\mathrm{Cl}, \mathrm{CLI}-\mathrm{Br}$ and CLI-Cl.

On these prepared samples, the anion exchange capacity (AEC), which indicates the maximum amount of anions exchangeable by $1 \mathrm{~g}$ of SMNZ, was estimated. Accordingly, $2.5 \mathrm{~g}$ of SMNZs was put in contact for 3 days, under continuous stirring and at $\mathrm{T}=25{ }^{\circ} \mathrm{C}$, with a $100 \mathrm{mM} \mathrm{KNO} 3(\mathrm{CAS}$ : 7757-79-1; M = $101.10 \mathrm{~g} / \mathrm{mol}$; Sigma Aldrich; assay: $>99.0 \%$ ) solution, changing and recovering the solution every $24 \mathrm{~h}$. The actual AEC of the SMNZ samples was estimated from the HPLC analysis of the recovered solutions, verifying at the same time the stability of the bilayer by checking the possible release of HDTMA.

\subsection{Ion Exchange Runs}

\subsubsection{Kinetics}

The ion exchange kinetics for the chosen $\mathrm{As}(\mathrm{V})$ onto set composites were examined. For this purpose, stock solutions of $\mathrm{KH}_{2} \mathrm{AsO}_{4}$ (CAS: 7784-41-0; $\mathrm{M}=180.03 \mathrm{~g} / \mathrm{mol}$; Sigma Aldrich, assay: $>97.0 \%$ ) in distilled water were prepared. Kinetic runs were conducted in batch conditions by contacting, under continuous mixing and at room temperature, $1 \mathrm{~L}$ of $\mathrm{As}(\mathrm{V})$ solution at an initial concentration of $100 \mathrm{mg} \mathrm{L}^{-1}$, with $1 \mathrm{~g}$ of each SMNZ in bromide and chloride form. At scheduled time intervals, $10 \mathrm{~mL}$ of the supernatant was withdrawn, centrifuged and the unloaded $\mathrm{As}(\mathrm{V})$ quantified by means of spectrophotometric assay. These concentrations were measured using ICP-OES (Perkin Elmer Optima $2100 \mathrm{DV})$.

\subsubsection{Isotherms}

Ion-exchange equilibrium data were also collected in batch, by contacting $1 \mathrm{~g}$ of Surfactant Modified Natural Zeolite- $\mathrm{X}\left(\mathrm{X}=\mathrm{Br}^{-}, \mathrm{Cl}^{-}\right)$with $30 \mathrm{~mL}$ solutions containing different amounts of $\mathrm{KH}_{2} \mathrm{AsO}_{4}(\mathrm{CAS}$ : 7784-41-0, $\mathrm{M}=180.03 \mathrm{~g} / \mathrm{mol}$, Sigma Aldrich, assay: $>97.0 \%$ ) at increasing concentrations ranging from 1 to $500 \mathrm{mg} \mathrm{L}^{-1}$, placed in $30 \mathrm{~mL}$ polyallomer centrifuge tubes. The samples were shaken at $25^{\circ} \mathrm{C}$ for $24 \mathrm{~h}$ (that from kinetic experiments was found to be enough to reach equilibrium). Once equilibrated, samples were centrifuged, and the liquid was analyzed for As via ICP-OES. The $\mathrm{pH}$ of the $\mathrm{As}(\mathrm{V})$ solutions was checked during both kinetic and thermodynamic runs and was between 6 and 7, which indicates $\mathrm{H}_{2} \mathrm{AsO}_{4}{ }^{-}$and $\mathrm{HAsO}_{4}{ }^{2-}$ as the main species present, according to literature data about the dependence of the arsenic speciation on $\mathrm{pH}$ [15]. Nevertheless, the thermodynamic tests were repeated under three different $\mathrm{pH}$ conditions $(4,7$ and 10), using a low $\mathrm{As}(\mathrm{V})$ concentration to not induce the saturation of the exchange capacity (AEC) and thus to be able to verify the effect of the $\mathrm{pH}$ which otherwise could be masked by higher concentrations, in order to identify the value that would maximize the anion uptake. $\mathrm{pH}$ was monitored with a $\mathrm{pH}$ meter (Thermo Scientific Orion Star A 211) and adjusted by adding suitable solutions whose effect on the exchange process can be considered negligible due to the very small amounts added.

\subsection{Dynamic Runs}

Besides the kinetic and thermodynamic characterization of the anionic exchange process, as previously described, some fixed-bed tests were performed in order to characterize the behaviour of the SMNZs under dynamic conditions, with the aim to estimate the dynamic exchange capacity, 
the selectivity and the efficiency of the removal process itself. Such tests were performed under severe conditions, i.e., an initial As concentration of $25 \mathrm{mg} \mathrm{L}^{-1}$ and a flow rate of $1 \mathrm{~mL} \mathrm{~min}^{-1}$, which would not necessarily correspond to real ones, but would give an indication of the ability of the material to remove the pollutant under practical operating conditions.

Each bed was prepared placing about $10 \mathrm{~g}$ of the modified zeolite sample, sieved at $35 \times 50$ mesh, in a glass column with an internal diameter of $10 \mathrm{~mm}$, and repeatedly tapping it to tightly compact the grains. The final length of each bed after compaction was about $250 \mathrm{~mm}$.

The experiments were carried out at room temperature $\left(25 \pm 2{ }^{\circ} \mathrm{C}\right)$ by feeding the column with a $\mathrm{As}(\mathrm{V})$ aqueous solution by means of a peristaltic pump (Pharmacia Fine Chemicals, P3) at a constant flow rate. Samples of the outlet solution were collected by means of a temporized sample collector (Pharmacia Fine Chemicals, PF3) and then analyzed for As(V) by ICP-OES. After exhaustion, and before a new eluting cycle, the SMNZ bed was regenerated using a solution of $1 \mathrm{M}$ of the suitable salt ( $\mathrm{NaCl}$ (CAS: 7647-14-5; $\mathrm{M}=58.44 \mathrm{~g} / \mathrm{mol}$; Sigma Aldrich; assay: $>99.0 \%$ ) or NaBr (CAS: 7647-15-6; $\mathrm{M}=102.89 \mathrm{~g} / \mathrm{mol}$; Sigma Aldrich; assay: $>99.0 \%)$ ).

\subsection{Modeling}

To evaluate the arsenic uptake mechanisms of SMNZs, equilibrium and kinetic data were fitted by several mathematical models [44,45]. Model parameters were determined by non-linear regression using the Generalized Reduced Gradient Algorithm, based on the assumption that non-linear regression provides the best results in term of fitting $[45,46]$.

\subsubsection{Kinetics Modeling}

As reported in literature [47,48], the kinetics of adsorption onto SMNZs generally follow a pseudo-first order (1) [49] or pseudo-second order (2) [50]. These models can be written as follow:

$$
\begin{gathered}
Q_{t}=Q_{0}\left(1-e^{-K_{1} t}\right) \\
Q_{t}=\frac{K_{2} Q_{0}^{2} t}{1+K_{2} Q_{0} t}
\end{gathered}
$$

where $Q_{t}\left(\mathrm{mg} \mathrm{g}^{-1}\right)$ is the amount of adsorbate loaded onto SMNZ as a function of time $t$ (min), $Q_{0}$ $\left(\mathrm{mg} \mathrm{g}^{-1}\right)$ is the adsorbate concentration at equilibrium, whereas $K_{1}$ and $K_{2}$ are the pseudo-first and the pseudo-second order kinetic constants, respectively.

\subsubsection{Equilibrium Modeling}

Concerning the equilibrium data, the Langmuir model is commonly used to quantify and compare the performance of different bio-mineral sorbents, such as SMNZs. On the other hand, Sips [51] and Toth [52] developed two more equations to model adsorption processes [44,53,54].

Langmuir (3), Sips (4) and Toth (5) equations are reported in the following:

$$
\begin{gathered}
S=S_{m} \frac{K C_{e}}{1+K C_{e}} \\
S=S_{m} \frac{\left(K C_{e}\right)^{n}}{1+\left(K C_{e}\right)^{n}} \\
S=S_{m} \frac{K C_{e}}{\left[1+\left(K C_{e}\right)^{n}\right]^{\frac{1}{n}}}
\end{gathered}
$$

where $S\left(\mathrm{mg} \mathrm{g}^{-1}\right)$ is the amount of solute adsorbed by the solid at equilibrium conditions; $C_{e}\left(\mathrm{mg} \mathrm{L}^{-1}\right)$ is the concentration of As in solution at equilibrium; $S_{m}\left(\mathrm{mg} \mathrm{g}^{-1}\right)$ is the maximum adsorption capacity 
at equilibrium; $K\left(\mathrm{~L} \mathrm{mg}^{-1}\right)$ is a constant related to the exchange energy, whereas $\mathrm{n}$ is a parameter related to heterogeneity of the system. If $n=1$, both Sips and Toth reduce to Langmuir equations.

\subsubsection{Dynamic Runs Modeling}

The dynamic parameters were obtained by evaluation of the resulting S-shaped breakthrough curves. First of all, the length of the Mass Transfer Zone (MTZ), $L_{z}$-i.e., the zone of the packed column where the active anion exchange is supposed to happen under dynamic conditions (according to Michaels mathematical approach, $\mathrm{m}$ [55])—was estimated. Therefore, $L_{z}$ can be computed from the following expression:

$$
L_{z}=L_{b} \frac{V_{t}-V_{b}}{F V_{t}-(1-F) V_{b}}
$$

where $L_{b}$ is the bed length, $V_{b}$ is the breakthrough volume, $V_{t}$ is the volume of the eluting solution at the bed exhaustion and $F$ is the symmetry index of the breakthrough curve, defined as:

$$
F=\frac{\int_{V_{b}}^{V_{t}}\left(C_{0}-C\right) d V}{C_{0}\left(V_{t}-V_{b}\right)}
$$

Here, $C_{0}$ and $C$ are the initial and the actual concentrations of the ion entering the SMZ micelle, respectively. The integral at the numerator can be estimated from the breakthrough plot through the evaluation of the area delimited by the abscissa axis, the horizontal line denoting the value of the original ion concentration, the vertical line having equation $V=V_{b}$ and the S-shaped curve. Given the uncertainty in evaluating the real values of $V_{b}$ and $V_{t}$, the breakthrough and exhaustion volumes have been estimated, according to a consolidate practice, at $0.05 C_{0}$ and $0.95 C_{0}$.

The $\mathrm{X}$-anion exchange capacity (X-AEC)-i.e., the exchange capacity of each sample under dynamic conditions $\left(C_{t}\right)$-was estimated in a similar way as described above, according to the following equation:

$$
C_{t}=\frac{\int_{0}^{V_{t}}\left(C_{0}-C\right) d V}{m}
$$

where $m$ is the mass of the exchanger. The Working Exchange Capacity (WEC or $C_{w}$ ) -that is, the profitable ion exchange capacity under the assumption that the maximum allowable concentration of the ingoing ion in the effluent is that reached at the breakthrough point-was estimated according to the following equation:

$$
C_{w}=\frac{\int_{0}^{V_{b}}\left(C_{0}-C\right) d V}{m}
$$

Knowing $C_{t}, C_{w}$ and the total anion exchange capacity (AEC), the dynamic selectivity (S), defined as the ratio between the $\mathrm{X}-\mathrm{AEC}$ and the total $\mathrm{AEC}$, which appraises the tuff preference in dynamic conditions for the ingoing anion, and the efficiency (E), namely the ratio between WEC and total AEC, can be easily calculated:

$$
\begin{aligned}
& S=\frac{C_{t}}{A E C} \\
& E=\frac{C_{w}}{A E C}
\end{aligned}
$$

The breakthrough curves were also modeled by the Thomas equation [56], which is applicable to processes whose reaction kinetics are reversible and obey a second-order law and whose thermodynamics follow the Langmuir isotherm. The Thomas equation calculates the maximum solid phase concentration of the solute on the exchanger and the exchange rate constant for a continuous exchange process. The equation can be conveniently linearized as follows:

$$
\ln \left(\frac{C_{0}}{C(t)}-1\right)=\frac{k_{T} q_{0} m}{Q}-\frac{k_{T} C_{0}}{Q} V(t)
$$


where $k_{T}\left(\mathrm{~L} \mathrm{mg}^{-1} \mathrm{~min}^{-1}\right)$ is the Thomas rate constant, $q_{0}\left(\mathrm{mg} \mathrm{g}^{-1}\right)$ is the equilibrium amount of As ions per gram of the exchanger (that coincides with the X-AEC of the exchanger), $Q$ is the eluent flow rate $\left(\mathrm{L} \min ^{-1}\right), V(t)$ is the effluent volume $(\mathrm{L})$ and $\mathrm{m}$ is the amount of exchanger in the column $(\mathrm{g})$.

\section{Results and Discussion}

\subsection{Sample Characterization}

The XRPD patterns of CLI and PHI samples are reported in Figure 2A,B. The CLI sample contains clinoptilolite as the only exchanger phase, while the PHI sample is more heterogeneous, containing at least three zeolitic exchangers, mainly phillipsite with minor amounts of chabazite and analcime.
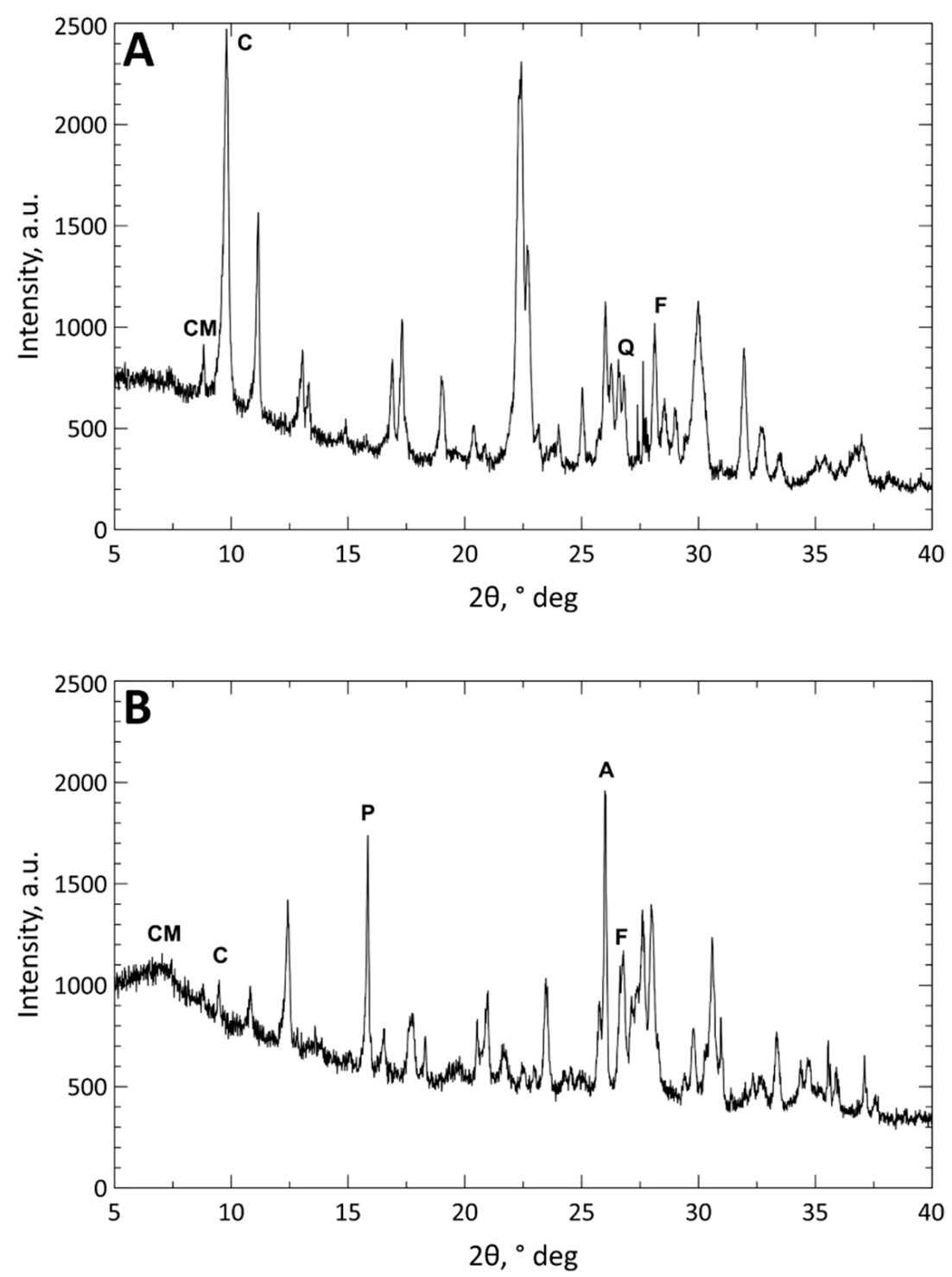

Figure 2. XRPD characterization of clinoptilolite-rich tuff (CLI) (A) and phillipsite-rich tuff (PHI) sample (B). $\mathrm{CM}=$ Clay Minerals, $\mathrm{C}=$ Clinoptilolite, $\mathrm{P}=$ Phillipsite, $\mathrm{F}=$ feldspar, $\mathrm{Q}=$ quartz, $\mathrm{A}=$ analcime.

Quantitative X-ray analysis carried out using the RIR/Rietveld method supplied the following mineralogical composition: 79\% clinoptilolite, $5 \%$ feldspar, $1 \%$ quartz, $15 \%$ clays minerals for CLI and $44 \%$ phillipsite, $4 \%$ chabazite, $10 \%$ analcime, $32 \%$ feldspar, $20 \%$ clays minerals for PHI, respectively. Concerning the clinoptilolite sample, XRPD analysis confirms that the sample consists of clinoptilolite 
as the only phase with exchange properties. Therefore, the CLI sample can be considered as a single exchanger containing only $21 \%$ of non-exchanging phase.

Concerning the PHI sample, the analysis underlined its heterogeneity, although phillipsite is the zeolite present in the maximum concentration. The second zeolite in order of abundance, the analcime, has a much denser microstructure than the other two (phillipsite and chabazite), which makes its contribution to the exchange process negligible, at least up to the end of our experiments. The last zeolitic phase, chabazite, is present in a very low concentration. This makes it possible to describe the PHI sample as a single exchanger phase with a $\mathrm{Si} / \mathrm{Al}$ ratio of 2.38 .

Table 1 reports the chemical analysis after acid digestion of the selected samples. Although it is a bulk analysis, it is possible to highlight how the CLI sample is mainly a potassic/calcic tuff, while PHI is a potassic/sodic/calcic tuff. This is perfectly in agreement with the genesis and origins of the two selected tuffs.

Table 1. Chemical analyses of selected samples (oxide wt.\%).

\begin{tabular}{ccc}
\hline & CLI (\%) & PHI (\%) \\
\hline $\mathrm{SiO}_{2}$ & 69.71 & 52.15 \\
$\mathrm{Al}_{2} \mathrm{O}_{3}$ & 11.74 & 18.56 \\
$\mathrm{Fe}_{2} \mathrm{O}_{3}$ & 1.21 & 0.20 \\
$\mathrm{MgO}$ & 0.31 & 0.20 \\
$\mathrm{CaO}$ & 2.30 & 2.35 \\
$\mathrm{Na}_{2} \mathrm{O}$ & 0.76 & 3.30 \\
$\mathrm{~K}_{2} \mathrm{O}$ & 4.41 & 7.54 \\
$\mathrm{H}_{2} \mathrm{O}$ & 12.80 & 15.73 \\
\hline
\end{tabular}

The CEC of the two samples was $1.97 \mathrm{meq}^{-1}$ and $2.03 \mathrm{meq}^{-1}$ for CLI and PHI, respectively. These relatively close values arise from the higher cation content of the phillipsite in the PHI sample that compensates for its amount, which is lower than that of clinoptilolite in the CLI sample. The ECEC values were $0.142 \mathrm{meq} \mathrm{g}^{-1}$ and $0.130 \mathrm{meq} \mathrm{g}^{-1}$, for CLI and PHI, respectively. Such values are for both materials roughly 1 out of 10 of the total exchange capacity, which accounts for the surface/bulk ratio of the tuff grains.

Finally, the AEC values obtained for the four samples are: CLI-Br $=0.142 \mathrm{meq} \mathrm{g}^{-1} ; \mathrm{CLI}-\mathrm{Cl}=$ 0.071 meq g $^{-1} ; \mathrm{PHI}-\mathrm{Br}=0.115 \mathrm{meq} \mathrm{g}^{-1} ; \mathrm{PHI}-\mathrm{Cl}=0.058$ meq g $^{-1}$.

The data show the following evidence:

- The AEC value of both HDTMA-Br modified samples is about equal to the ECEC values: this indicates that a double layered micelle is formed on the zeolite surface;

- On the contrary, the AEC value of both HDTMA-Cl modified samples is lower than the ECEC values: in this case, a patchy bilayer is formed on the zeolite surface.

This demonstrates that the counterion affects the micelle formation more than the zeolite present in the sample: even if the genesis and structure of the two tuffs are different, the morphology of the zeolites present is almost the same, characterized by a rigid framework with internal channels oriented along two preferential directions (planar-like structure). This type of morphology, together with the high $\mathrm{Si} / \mathrm{Al}$ ratio typical of these natural zeolites, leaves many free surfaces available to interact with large surfactant molecules, which, however, cannot access the most internal cationic sites of the zeolitic framework, but are able to micellize on the surface of the same tuffs. The obtained results are confirmed by previous experiments in which a clinoptilolite-rich sample coming from New Mexico was also used [31,42]. Lastly, through the HPLC analysis of the liquid phase, no release of HDTMA by SMNZs was found, at least under the conditions in which the AEC evaluation was performed. This indicates a fair stability of the surfactant zeolite system both in the case of patchy and complete bilayer formation. Moreover, already in previous works [37], it was pointed out that a loss in surfactant could occur in extreme stirring or washing conditions-a situation not applied in this research. 


\subsection{Ion Exchange Runs}

\subsubsection{Preliminary Runs}

As previously pointed out, the effect of the $\mathrm{pH}$ on the removal process was checked, prior to further investigating the behavior of the SMNZs, by performing some preliminary tests at different $\mathrm{pH}$ values. In fact, it is well known that as the $\mathrm{pH}$ changes, both the surface charge of the SMNZ and the As speciation will change. The effect of $\mathrm{pH}$ on the As species uptake is reported in Figure 3 for CLI-Br and PHI-Br samples.

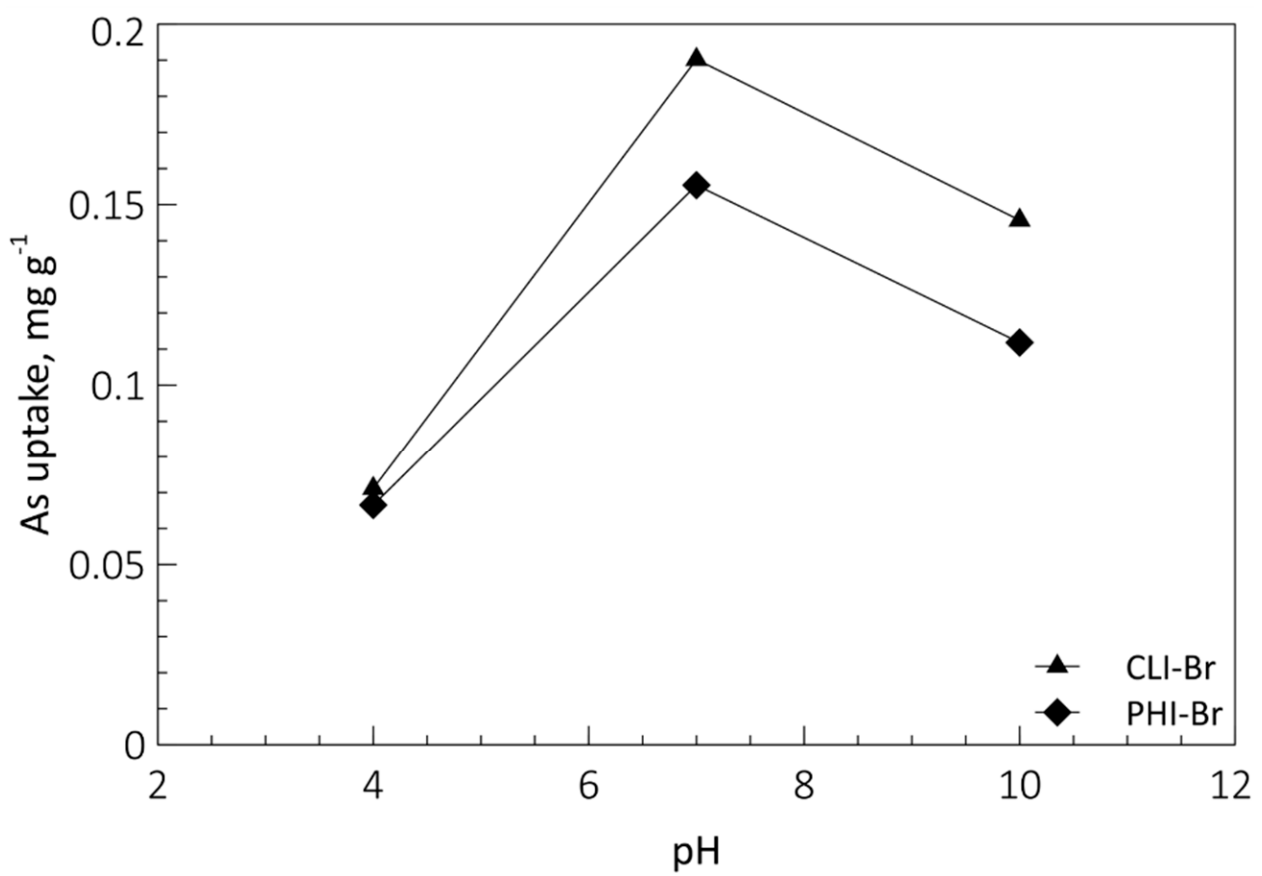

Figure 3. Effect of $\mathrm{pH}$ on the $\mathrm{As}(\mathrm{V})$ uptake in CLI-Br and $\mathrm{PHI}-\mathrm{Br}$ at $\mathrm{T}=25^{\circ} \mathrm{C}$.

From the comparison of the equilibrium values obtained at different $\mathrm{pH}$, it can be observed that the higher uptake occurs at $\mathrm{pH}=7$ for both SMNZs. These results, supported by literature data [41], seem to indicate that the $\mathrm{SMZ}$ is selective towards $\mathrm{HAsO}_{4}{ }^{2-}$ against $\mathrm{H}_{2} \mathrm{AsO}_{4}{ }^{-}$, because the concentration of the former increases with the $\mathrm{pH}$, while the positive charge (and consequently its ability to remove anions) of the SMZ decreases with the $\mathrm{pH}$ (actually, as previously reported [57], the point of zero charge (PZC) of the modified zeolites is around 8). The most favorable $\mathrm{pH}$ condition is then met when (at $\mathrm{pH}$ around 7) the higher amount of $\mathrm{HAsO}_{4}{ }^{2-}$ (the species with the greatest affinity towards the exchanger) is associated with the positively charged surface of the exchanger [41]. Concerning the CLI-Cl and $\mathrm{PHI}-\mathrm{Cl}$ samples, similar results have been obtained (here not reported for the sake of brevity).

\subsubsection{Kinetics of the Anion Exchange}

Figure 4 shows the kinetics of the anion exchange of As species on CLI-Br, CLI-Cl (Figure 4A), $\mathrm{PHI}-\mathrm{Br}$ and $\mathrm{PHI}-\mathrm{Cl}$ (Figure 4B) samples. All the kinetics appear reasonably fast: the equilibrium conditions had already been reached after just $50 \mathrm{~min}$. For each tuff, the HDTMA-Br modified sample is always more effective than the HDTMA-Cl modified one: for PHI-based SMNZ samples, the maximum loading of As for PHI-Br is $4.21 \mathrm{mg} \mathrm{g}^{-1}$, while for PHI-Cl is $1.20 \mathrm{mg} \mathrm{g}^{-1}$. 

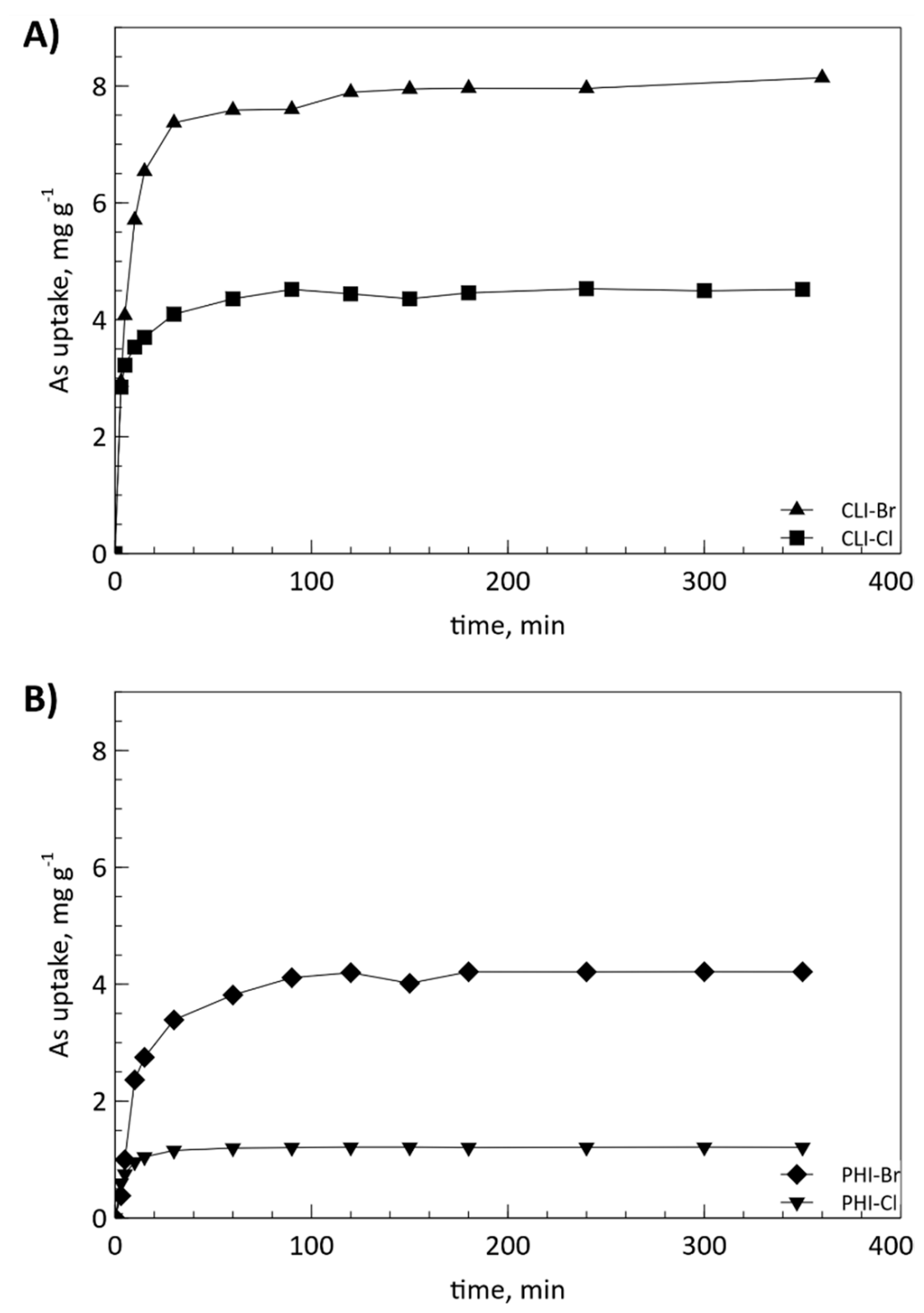

Figure 4. As exchange kinetics for PHI-based (A) CLI-based (B) Surface modified natural zeolites (SMNZs).

The same thing holds true for the clinoptilolite-based SMNZ samples: the maximum loading value for CLI-Br is $8.14 \mathrm{mg} \mathrm{g}^{-1}$, while the value for CLI-Cl is $4.52 \mathrm{mg} \mathrm{g}^{-1}$. These results confirm once again how the surfactant that has $\mathrm{Br}^{-}$as a counterion generates a much more complete and compact micellar structure on the surface of the zeolite compared to the surfactant that has $\mathrm{Cl}^{-}$as a counterion, which can generate only a patchy bilayer. This results in the greater AEC of both Br-based SMNZs, which is practically equal to the ECEC of the two samples, while the surface AEC of the samples modified with HDTMA-Cl is equal to half of the ECEC.

Moreover, clinoptilolite-based SMNZs can always remove more As than phillipsite-based ones. This could be justified by the ECEC of the former that is greater due to a higher amount of zeolite in the sample: the mineralogical analysis showed that while the clinoptilolitic tuff has a zeolite content of $79 \%$, the phillipsitic tuff reaches a maximum of $58 \%$ (even if the analcime contribution to the exchange is very low). However, both the modified samples were not able, in any of the experiments, to exploit the totality of their AEC, as reported in Table 2, in which the AEC, for practical purposes, is reported as $\mathrm{mg} \mathrm{g}^{-1}$ of exchangeable arsenic. 
Table 2. Anion exchange capacity (AEC), As uptake and exploited AEC\% for SMNZ samples.

\begin{tabular}{cccc}
\hline Sample & AEC $\left[\mathbf{m g ~ g}^{-\mathbf{1}}\right.$ ] & As Uptake $\left[\mathrm{mg} \mathrm{g}^{-\mathbf{1}}\right.$ ] & \%AEC \\
\hline PHI-Br & 8.62 & 4.21 & 48.86 \\
PHI-Cl & 4.35 & 1.21 & 27.62 \\
CLI-Br & 10.64 & 8.14 & 76.51 \\
CLI-Cl & 5.32 & 4.52 & 84.97 \\
\hline
\end{tabular}

This evidence is once again justified by the steric hindrance and shape complexity of the As anions compared to the "simple" $\mathrm{Br}^{-}$and $\mathrm{Cl}^{-}$. Such complexity forces a rearrangement of the micelle (either bilayer or patchy bilayer) to allow the entrance of the As species into its structure. This micellar rearrangement prevents the complete exploitation of its anionic exchange sites, because, as already proven [32], the micellar structure is not perfectly flexible and has limited capacity to accommodate complex anions.

Kinetic exchange data were modeled with the pseudo-first and pseudo-second order equations (see Section 2.4.1). The results are shown in Figure 5 and Table 3.
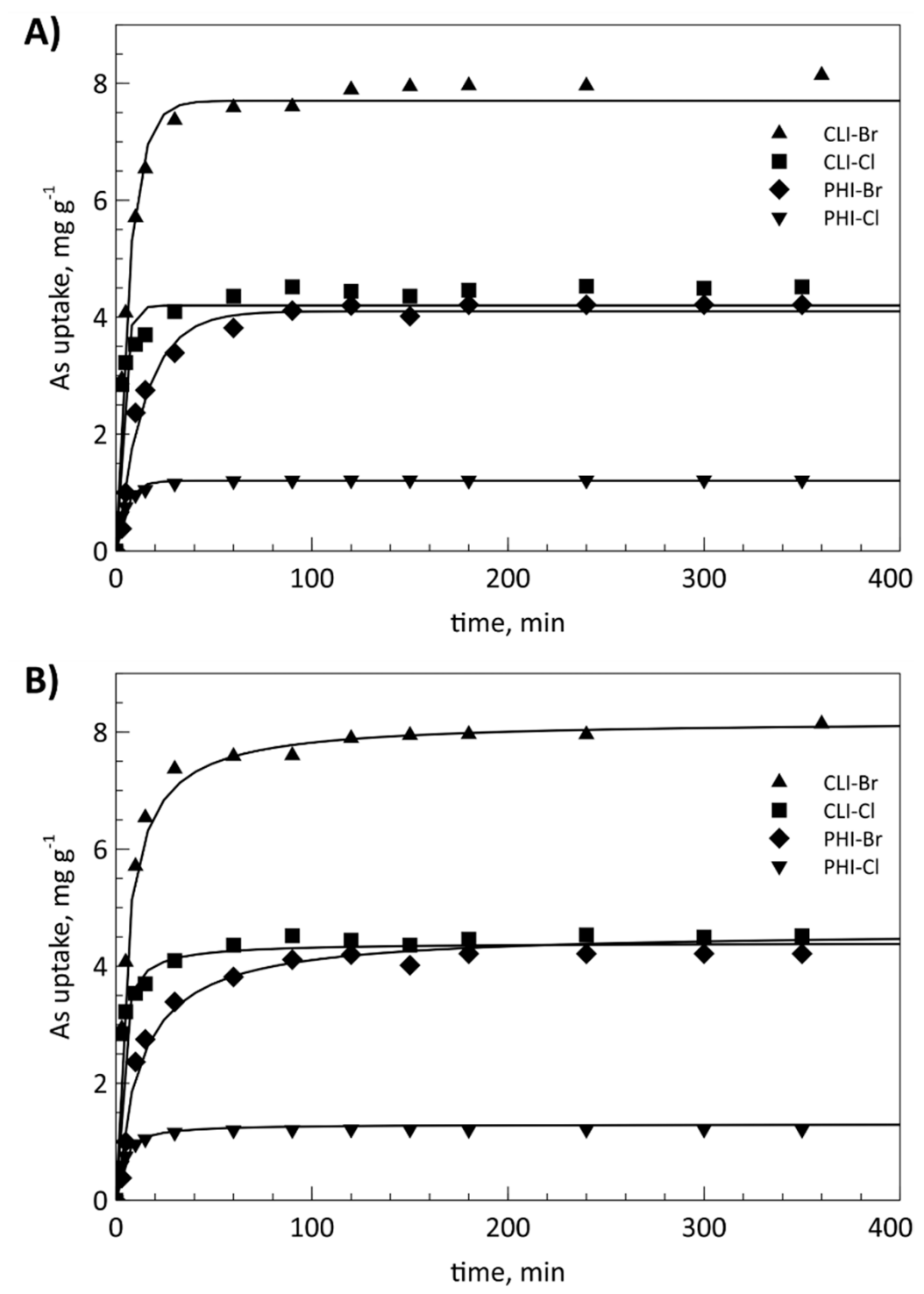

Figure 5. Fitting of the As kinetics with a pseudo-first order (A) and pseudo-second order equation (B). 
Table 3. Kinetic parameters.

\begin{tabular}{|c|c|c|c|c|c|}
\hline \multirow[t]{2}{*}{ Sample } & \multirow[t]{2}{*}{ Mathematical Model } & \multicolumn{4}{|c|}{ Parameters } \\
\hline & & $\begin{array}{c}\mathrm{K}_{1} \\
\left(\min ^{-1}\right)\end{array}$ & $\begin{array}{c}\mathrm{K}_{2} \\
\left(\mathrm{~g} \mathrm{mg}^{-1} \min ^{-1}\right)\end{array}$ & $\begin{array}{c}S_{m} \\
\left(\mathrm{mg} \mathrm{g}^{-1}\right)\end{array}$ & $\mathbf{R}^{2}$ \\
\hline \multirow[t]{2}{*}{ CLI-Br } & Pseudo-first order & 0.143 & & 7.7 & 0.995 \\
\hline & Pseudo-second order & & 0.025 & 8.2 & 0.995 \\
\hline \multirow[t]{2}{*}{ CLI-Cl } & Pseudo-first order & 0.309 & & 4.2 & 0.956 \\
\hline & Pseudo-second order & & 0.116 & 4.4 & 0.991 \\
\hline \multirow[t]{2}{*}{ PHI-Br } & Pseudo-first order & 0.068 & & 4.1 & 0.984 \\
\hline & Pseudo-second order & & 0.018 & 4.6 & 0.981 \\
\hline \multirow[t]{2}{*}{ PHI-Cl } & Pseudo-first order & 0.192 & & 1.2 & 0.967 \\
\hline & Pseudo-second order & & 0.248 & 1.3 & 0.999 \\
\hline
\end{tabular}

From the characteristic parameters of the models, as well as from the trend of the model curves reported in Figure 5, it is clear how the kinetics of anion exchange are closer to a pseudo-second order trend, as also confirmed by the obtained values of $R^{2}$.

\subsubsection{Thermodynamics of Anion Exchange}

Figure 6 shows the As species exchange isotherms in SMNZ-Br and SMNZ-Cl, obtained at $\mathrm{pH}=7$. The graphs show the equilibrium concentration of the ingoing cation in the solid phase $\left(\mathrm{mg} \mathrm{g}^{-1}\right)$ as a function of its equilibrium concentration in the liquid phase $\left(\mathrm{mg} \mathrm{L}^{-1}\right)$.

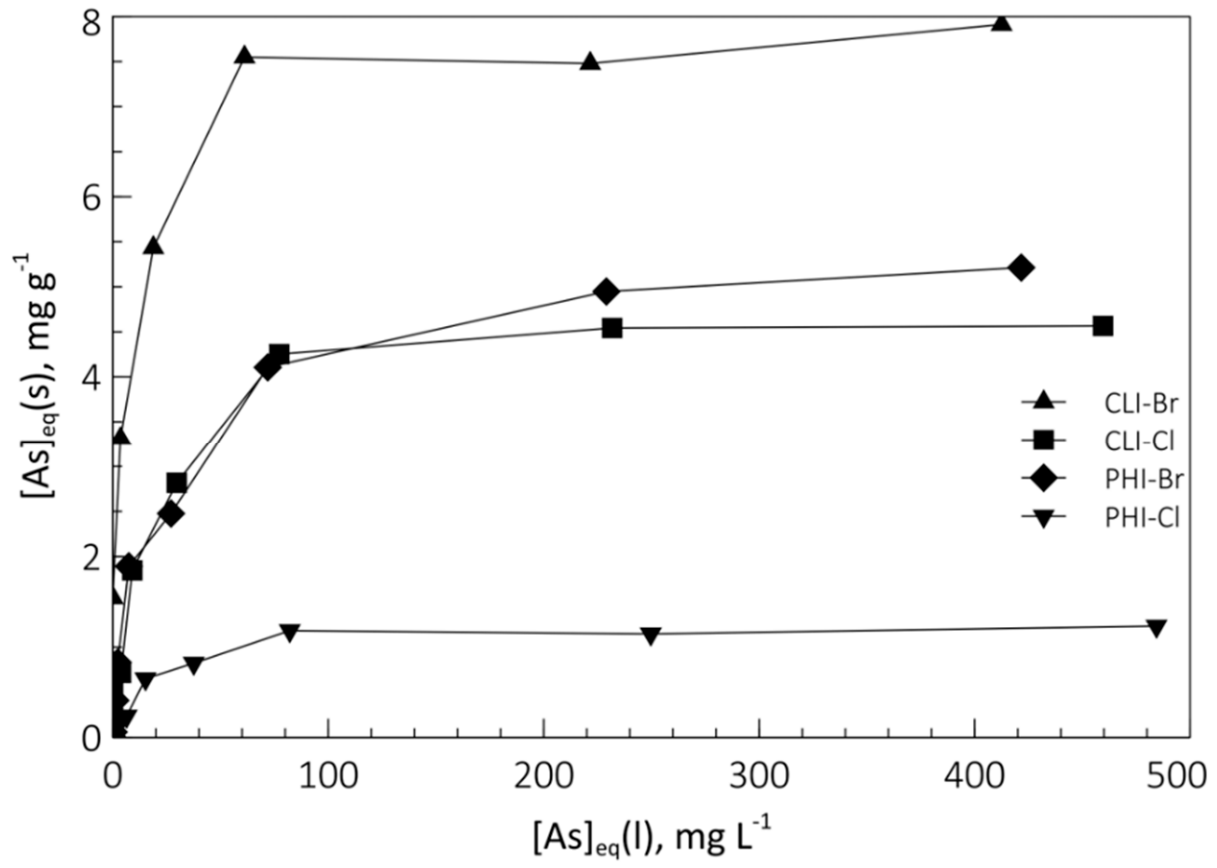

Figure 6. As exchange isotherms for SMNZ samples at a $\mathrm{T}=25^{\circ} \mathrm{C}$.

Isotherms data allow us to state that:

1. Samples obtained with the use of HDTMA-Br perform better than those obtained with HDTMA-Cl: concerning the phillipsite-rich tuff, maximum exchange is of $5.2 \mathrm{mg} \mathrm{g}^{-1}$ for PHI-Br and $1.2 \mathrm{mg} \mathrm{g}^{-1}$ for PHI-Cl, while for clinoptilolite-rich tuff, maximum exchange is $7.9 \mathrm{mg} \mathrm{g}^{-1}$ for CLT-Br and $4.6 \mathrm{mg} \mathrm{g}^{-1}$ for CLT-Cl. This is once again justified by what was previously verified about the micelle formation on the zeolitic surface: if the counterion that balances the positive charge of 
the nitrogenous head of $\mathrm{HDTMA}^{+}$is $\mathrm{Br}^{-}$, the micellar structure that is obtained on the zeolite surface is complete and compact (the bilayer has an anion exchange capacity, AEC, equal to its ECEC). If $\mathrm{Cl}^{-}$is the counterion, the micellar structure that is generated is like a patchy bilayer (partial micelle structure), which has obviously less exchangeable anions with respect to the previous case.

2. Clinoptilolite modified samples perform better than phillipsite modified samples. This can be due to the different density of HDTMA in the micelle, that in turn depends on the $\mathrm{Al}$ on the surface of the zeolite: the higher (4.90) $\mathrm{Si} / \mathrm{Al}$ ratio of clinoptilolite will produce a micelle sparser than that produced on the phillipsite surface $(\mathrm{Si} / \mathrm{Al}$ ratio $=2.38)$. This allows a higher amount of complex anions such as $\mathrm{HAsO}_{4}{ }^{2-}$ and $\mathrm{H}_{2} \mathrm{AsO}_{4}{ }^{-}$to enter the micellar structure, as the micelle can better rearrange itself to accommodate them.

3. The As anion can only partially exploit the surface anionic exchange capacity of both SMNZs investigated. This is a direct consequence of what was stated earlier: the uptake of a complex anion forces a rearrangement of the micellar structure, which probably displaces some exchange sites and makes them unavailable for further exchange.

The equilibrium data were modeled with Langmuir, Sips and Toth equations-already described in the Materials and Method section (see Section 2.4.2). Figure 7 shows the results of these modelings, while Table 4 shows the significant parameters determined from each best fitting curve.

Table 4. Isotherms parameters.

\begin{tabular}{|c|c|c|c|c|c|}
\hline \multirow[t]{2}{*}{ Samples } & \multirow[t]{2}{*}{ Mathematical Model } & \multicolumn{4}{|c|}{ Parameters } \\
\hline & & $\mathrm{K}_{1}\left(\mathrm{~L} \mathrm{mg}^{-1}\right)$ & $\mathbf{n}$ & $S_{m}\left(m g^{-1}\right)$ & $\mathbf{R}^{2}$ \\
\hline \multirow[t]{3}{*}{$\mathrm{PHI}-\mathrm{Br}$} & Langmuir & 0.048 & & 5.34 & 0.983 \\
\hline & Sips & 0.033 & 0.79 & 5.99 & 0.990 \\
\hline & Toth & 0.095 & 0.57 & 6.48 & 0.991 \\
\hline \multirow[t]{3}{*}{ PHI-Cl } & Langmuir & 0.055 & & 1.29 & 0.983 \\
\hline & Sips & 0.060 & 1.19 & 1.25 & 0.985 \\
\hline & Toth & 0.042 & 1.41 & 1.23 & 0.986 \\
\hline \multirow[t]{3}{*}{ CLI -Br } & Langmuir & 0.172 & & 7.86 & 0.962 \\
\hline & Sips & 0.161 & 0.79 & 8.19 & 0.972 \\
\hline & Toth & 0.275 & 0.74 & 8.22 & 0.996 \\
\hline \multirow[t]{3}{*}{ CLI-Cl } & Langmuir & 0.058 & & 4.87 & 0.982 \\
\hline & Sips & 0.058 & 1.02 & 4.84 & 0.982 \\
\hline & Toth & 0.053 & 1.09 & 4.79 & 0.983 \\
\hline
\end{tabular}

The modeling results show that the Toth model seems to be the one that made the experimental thermodynamic data dense; this is also confirmed by the values of $\mathrm{R}^{2}$, which are always higher for the Toth model. In any case, since the Langmuir isotherm is a two-parameter model that assumes adsorption on a defined number of sites that have the same affinity for the adsorbate, which forms a monolayer, and considering that the exchange of ions should not give multilayer formation, we will consider the Langmuir isotherm model as the most appropriate for our system.

Lastly, the data in the table confirm the maximum uptake values recorded by the thermodynamic tests in which the maximum value of removable As was 5.34 and $1.29 \mathrm{mg} \mathrm{g}^{-1}$ for the PHI-Br and PHI-Cl samples, respectively, and 7.86 and $4.87 \mathrm{mg} \mathrm{g}^{-1}$ for CLI-Br and CLI-Cl samples, respectively. 

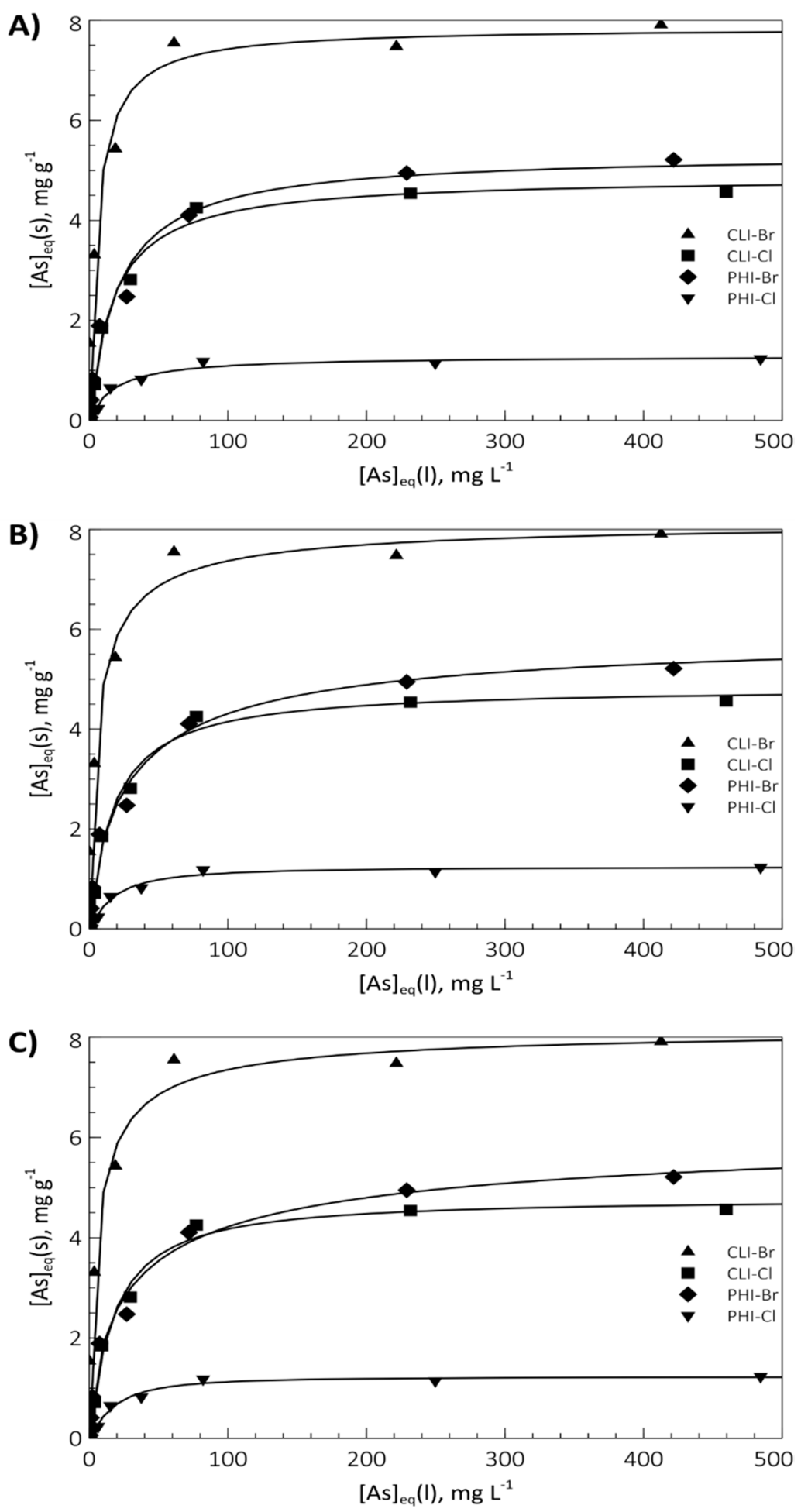

Figure 7. As adsorption isotherms and best fitting Langmuir (A), Sips (B) and Toth (C) curves.

\subsection{Dynamic Runs}

Figure 8 reports the breakthrough curves for all investigated SMNZs. From the inspection of the plotted data, it is evident that all samples have a similar performance up to breakthrough, being able to treat about 20-30 bed volumes. In particular, the best and worst results were obtained for CLI-Br ( 30 bed volumes, $610 \mathrm{~mL}$ ) and CLI-Cl ( 22 bed volumes, $440 \mathrm{~mL}$ ), respectively, while PHI-based samples were quite insensitive to their anionic form (about 25 bed volumes, corresponding to about $490 \mathrm{~mL}$ ). 

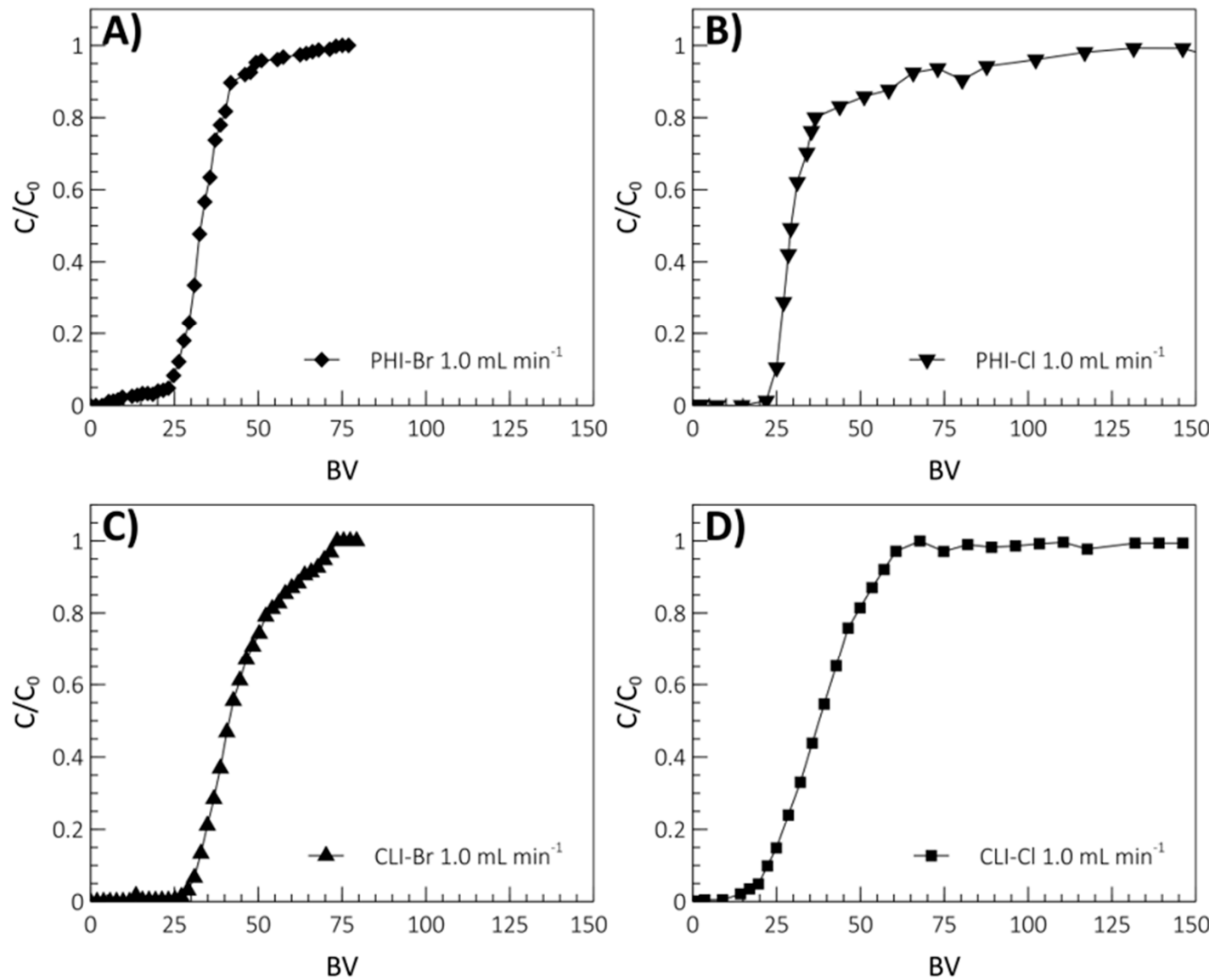

Figure 8. As breakthrough curves for PHI-Br (A), $\mathrm{PHI}-\mathrm{Cl}$ (B), CLI-Br (C) and CLI-Cl (D) samples.

Besides the treated volume up to breakthrough, the curves show different slopes, which indicate different mass transfer zones. Furthermore, in some case, a change in the curve slope is clear, especially in the case of PHI-based samples: such strange behavior can be due to another active phase (chabazite, analcime) which exchanges As, but at a slower rate.

To obtain a better estimation of the mass transfer zone, the calculation was performed on the curve data ranging from the breakthrough point up to the change of slope. Results are reported in Table 5: the PHI-based samples showed the shortest MTZ, while CLI-based the longest one.

Table 5. Dynamic parameters from breakthrough curves.

\begin{tabular}{|c|c|c|c|c|c|c|}
\hline Sample & MTZ, mm & M-AEC, mg g $^{-1}$ & WEC, $\mathrm{mg} \mathrm{g}^{-1}$ & $\mathrm{AEC}, \mathrm{mg} \mathrm{g}^{-1}$ & $S$ & $\mathbf{E}$ \\
\hline CLI-Br & 209.12 & 1.12 & 0.73 & 10.64 & 0.11 & 0.07 \\
\hline CLI-Cl & 234.28 & 0.95 & 0.53 & 5.32 & 0.18 & 0.10 \\
\hline PHI-Br & 161.7 & 0.79 & 0.53 & 8.62 & 0.09 & 0.06 \\
\hline $\mathrm{PHI}-\mathrm{Cl}$ & 141.04 & 1.03 & 0.66 & 4.35 & 0.24 & 0.15 \\
\hline
\end{tabular}

Such evidence could be due to a faster diffusion of the As ions on the particles surface, allowed by a more dense micelle structure, as previously seen. Furthermore, the different amount of As (V) removed, if compared with the batch kinetic tests, could be due to the high elution rate selected for the present runs, higher than the diffusion rate and the exchange kinetics; thus not giving time to fully exploit the AEC of the tested SMNZs. The obtained values of the Thomas model $\mathrm{k}$ constant (see Table 6) are consistent with this hypothesis, being higher for PHI-based samples. 
Table 6. Thomas parameters from breakthrough curves.

\begin{tabular}{cccc}
\hline Sample & $\mathbf{k}, \mathbf{L} / \mathbf{m i n} / \mathbf{m g}$ & $\mathbf{q}, \mathbf{m g} / \mathbf{g}$ & $\mathbf{R}^{\mathbf{2}}$ \\
\hline CLI-Br & $2.52 \mathrm{E}-04$ & 1.12 & 0.94 \\
CLI-Cl & $2.83 \mathrm{E}-04$ & 0.94 & 0.99 \\
PHI-Br & $3.78 \mathrm{E}-04$ & 0.79 & 0.95 \\
PHI-Cl & $5.53 \mathrm{E}-04$ & 0.86 & 0.92 \\
\hline
\end{tabular}

Among the four samples, $\mathrm{PHI}-\mathrm{Cl}$ showed the best performances in terms of selectivity $(0.24)$ and efficiency $(0.15$, Table 5): such values, although quite low, were obtained under severe conditions, and should be considered only for the sake of comparison among the four samples. The q values obtained from the Thomas model are also in very good agreement with the M-AEC obtained with the Michaels approach, except for the PHI-Cl sample, which suffers from a noticeable change in slope.

\section{Conclusions}

The present paper reports the results of an investigation of the possible use of surface-modified phillipsite- and clinoptilolite-rich tuffs as alternative ion exchangers for removing As from wastewater. Several surfactant-modified natural zeolite (SMNZ) exchangers were prepared by contacting tuff samples with HDTMA-Br or HDTMA-Cl solutions under continuous flow. On the obtained samples, the estimation of the anionic exchange capacity together with a kinetic and thermodynamic characterization was performed in batch conditions, while a fixed-bed test was also performed in order to characterize their behaviour under severe dynamic conditions.

The influence of $\mathrm{pH}$ on As removal was preliminarily investigated, showing that the best performances were obtained for neutral $\mathrm{pH}$ values. For each tuff, modification with HDTMA-Br produced samples with an exchange capacity higher than those modified with HDTMA-Cl, suggesting the formation of a complete and compact micellar structure, opposite to the patchy bilayer obtained on the samples modified with HDTMA-Cl. Kinetic tests demonstrated that As removal is in all cases reasonably fast: it reached $80 \%$ in $1 \mathrm{~h}$ and $100 \%$ in $2 \mathrm{~h}$. Data modeling results suggested that the ion exchange process follows a pseudo-second order kinetic. The thermodynamic tests were satisfactorily modeled with the Langmuir equation, confirming the better performance of the Br-modified samples over the $\mathrm{Cl}$-modified ones: the maximum amount of removable As was $7.86 \mathrm{mg} \mathrm{g}^{-1}$ for CLI-Br sample.

Moreover, the dynamic tests showed that every sample was able to treat at least 22 bed volumes: the CLI-Br sample showed the best performance (30 bed volumes), even if the PHI-Cl sample showed slightly higher efficiency and selectivity. Such results suggest a possible use of SMNZs as ion exchangers for the removal of As from wastewaters.

Lastly, as also verified in previous papers [32], there is a different selectivity on SMNZs for various anions present in waters. Therefore, it is important to study the effects of these possible interfering cations. However, in this first study, it was intended to verify only the removal efficiency of the As (V) by our modified zeolite supports (mainly as regards phillipsite rich-tuff). Future research, which have already begun, will be directed at verifying (with appropriate kinetic tests) the effect of the presence of other anionic species; this will certainly give us more complete information on the removal efficiency of our SMNZs.

Author Contributions: B.d.G.: Conceptualization, supervision, validation. P.A.: methodology and, formal analysis. B.L.: visualization and writing—original draft. B.G.: investigation and data curation. Antonio Peluso: investigation and, resources. D.C.: project administration and writing-review and editing. All authors have read and agreed to the published version of the manuscript.

Funding: This research received no external funding.

Acknowledgments: The authors wish to acknowledge the European Union and the Campania Region for the financial support in the frame of the POR-FESR 2014-2020 Programme (IDRICA project-CUP B63D18000310007 SURF 18031BP000000001).

Conflicts of Interest: The authors declare no conflict of interest. 


\section{References}

1. Xu, Y.H.; Nakajima, T.; Ohki, A. Adsorption and removal of arsenic(V) from drinking water by aluminumloaded Shirasu-zeolite. J. Hazard. Mater. 2002, 92, 275-287. [CrossRef]

2. Shevade, S.; Ford, R.G. Use of synthetic zeolites for arsenate removal from pollutant water. Water Res. 2004, 38, 3197-3204. [CrossRef] [PubMed]

3. Jomova, K.; Jenisova, Z.; Feszterova, M.; Baros, S.; Liska, J.; Hudecova, D.; Rhodes, C.J.; Valko, M. Arsenic: Toxicity, oxidative stress and human disease. J. Appl. Toxicol. 2011, 31, 95-107. [CrossRef] [PubMed]

4. Smedley, P.L.; Kinniburgh, D.G. A review of the source, behaviour and distribution of arsenic in natural waters. Appl. Geochem. 2002, 17, 517-568. [CrossRef]

5. Rubel, F., Jr. Design Manual: Removal of Arsenic from Drinking Water by Adsorptive Media; United States Environmental Protection Agency: Washington, DC, USA, 2003.

6. Ferguson, J.F.; Gavis, J. A review of the arsenic cycle in natural waters. Water Res. 1972, 6, 1259-1274. [CrossRef]

7. Ungureanu, G.; Santos, S.; Boaventura, R.; Botelho, C. Arsenic and antimony in water and wastewater: Overview of removal techniques with special reference to latest advances in adsorption. J. Environ. Manag. 2015, 151, 326-342. [CrossRef]

8. Gulens, J.; Champ, D.R.; Jackson, R.E. Influence of redox environments on the mobility of arsenic in ground water. In Proceedings of the ACS Symposium Series, Chalk River, ON, CA, 25-26 April 1979.

9. $\mathrm{Li}, \mathrm{Z}$. Use of surfactant-modified zeolite as fertilizer carriers to control nitrate release. Microporous Mesoporous Mater. 2003, 61, 181-188. [CrossRef]

10. Ihsanullah, I.; Abbas, A.; Al-Amer, A.M.; Laoui, T.; Al-Marri, M.J.; Nasser, M.S.; Khraisheh, M.; Atieh, M.A. Heavy metal removal from aqueous solution by advanced carbon nanotubes: Critical review of adsorption applications. Sep. Purif. Technol. 2016, 157, 141-161. [CrossRef]

11. Daus, B.; Wennrich, R.; Weiss, H. Sorption materials for arsenic removal from water: A comparative study. Water Res. 2004, 38, 2948-2954. [CrossRef]

12. Maeda, S.; Ohki, A.; Saikoji, S.; Naka, K. Iron(1ll) Hydroxide-Loaded Coral Limestone as an Adsorbent for Arsenic(lll) and Arsenic(V). Sep. Sci. Technol. 1992, 27, 681-689. [CrossRef]

13. Ohki, A.; Nakayachigo, K.; Naka, K.; Maeda, S. Adsorption of inorganic and organic arsenic compounds by aluminium-loaded coral limestone. Appl. Organomet. Chem. 1996, 10, 747-752. [CrossRef]

14. Xu, X.; Lin, L.; Papelis, C.; Xu, P. Sorption of arsenic from desalination concentrate onto drinking water treatment solids: Operating conditions and kinetics. Water 2018, 10, 96. [CrossRef]

15. Kuhlmeier, P.D. Sorption and desorption of arsenic from sandy soils: Column studies. Soil Sediment Contam. 1997, 6, 21-36. [CrossRef]

16. Bhatnagar, A.; Hogland, W.; Marques, M.; Sillanpää, M. An overview of the modification methods of activated carbon for its water treatment applications. Chem. Eng. J. 2013, 219, 499-511. [CrossRef]

17. Chen, W.; Parette, R.; Zou, J.; Cannon, F.S.; Dempsey, B.A. Arsenic removal by iron-modified activated carbon. Water Res. 2007, 41, 1851-1858. [CrossRef]

18. Gallios, G.P.; Tolkou, A.K.; Katsoyiannis, I.A.; Stefusova, K.; Vaclavikova, M.; Deliyanni, E.A. Adsorption of arsenate by nano scaled activated carbon modified by iron and manganese oxides. Sustainability 2017, 9, 1684. [CrossRef]

19. Camacho, L.M.; Ponnusamy, S.; Campos, I.; Davis, T.A.; Deng, S. Evaluation of Novel Modified Activated Alumina as Adsorbent for Arsenic Removal. In Handbook of Arsenic Toxicology; Academic Press: Waltham, MA, USA, 2015; ISBN 9780124199552.

20. Karmacharya, M.S.; Gupta, V.K.; Tyagi, I.; Agarwal, S.; Jha, V.K. Removal of As(III) and As(V) using rubber tire derived activated carbon modified with alumina composite. J. Mol. Liq. 2016, 216, 836-844. [CrossRef]

21. Yang, H.; Wang, Y.; Bender, J.; Xu, S. Removal of Arsenate and Chromate by Lanthanum-modified Granular Ceramic Material: The Critical Role of Coating Temperature. Sci. Rep. 2019, 9, 1-12. [CrossRef]

22. Pérez, J.; Toledo, L.; Campos, C.H.; Rivas, B.L.; Yañez, J.; Urbano, B.F. Organic-inorganic interpenetrated hybrids based on cationic polymer and hydrous zirconium oxide for arsenate and arsenite removal. Chem. Eng. J. 2016, 287, 744-754. [CrossRef]

23. Taleb, K.; Markovski, J.; Milosavljević, M.; Marinović-Cincović, M.; Rusmirović, J.; Ristić, M.; Marinković, A. Efficient arsenic removal by cross-linked macroporous polymer impregnated with hydrous iron oxide: Material performance. Chem. Eng. J. 2015, 279, 66-78. [CrossRef] 
24. Wang, S.; Gao, B.; Li, Y.; Creamer, A.E.; He, F. Adsorptive removal of arsenate from aqueous solutions by biochar supported zero-valent iron nanocomposite: Batch and continuous flow tests. J. Hazard. Mater. 2017, 322, 172-181. [CrossRef] [PubMed]

25. Bakshi, S.; Banik, C.; Rathke, S.J.; Laird, D.A. Arsenic sorption on zero-valent iron-biochar complexes. Water Res. 2018, 137, 153-163. [CrossRef] [PubMed]

26. Pattanayak, J.; Mondal, K.; Mathew, S.; Lalvani, S.B. A Parametric evaluation of the removal of As(V) and As(III) by carbon-based adsorbents. Carbon N.Y. 2000, 38, 589-596. [CrossRef]

27. Manju, G.N.; Raji, C.; Anirudhan, T.S. Evaluation of coconut husk carbon for the removal of arsenic from water. Water Res. 1998, 32, 3062-3070. [CrossRef]

28. Colella, C. Natural zeolites in environmentally friendly processes and applications. Stud. Surf. Sci. Catal. 1999, 125, 641-655.

29. De Gennaro, B.; Aprea, P.; Colella, C.; Buondonno, A. Comparative ion-exchange characterization of zeolitic and clayey materials for pedotechnical applications-Part 1: Interaction with noxious cations. J. Porous Mater. 2007, 14, 349-356. [CrossRef]

30. Colella, A.; de Gennaro, B.; Salvestrini, S.; Colella, C. Surface interaction of humic acids with natural and synthetic phillipsite. J. Porous Mater. 2015, 22, 501-509. [CrossRef]

31. Li, Z.; Bowman, R.S. Counterion effects on the sorption of cationic surfactant and chromate on natural clinoptilolite. Environ. Sci. Technol. 1997, 31, 2407-2412. [CrossRef]

32. De Gennaro, B.; Catalanotti, L.; Bowman, R.S.; Mercurio, M. Anion exchange selectivity of surfactant modified clinoptilolite-rich tuff for environmental remediation. J. Colloid Interface Sci. 2014, 430, 178-183. [CrossRef]

33. Li, Z. Chromate transport through surfactant-modified zeolite columns. Gr. Water Monit. Remediat. 2006, 23, 117-124. [CrossRef]

34. Li, Z.; Alessi, D.; Allen, L. Influence of Quaternary Ammonium on Sorption of Selected Metal Cations onto Clinoptilolite Zeolite. J. Environ. Qual. 2002, 31, 1106-1114. [CrossRef] [PubMed]

35. Li, Z.; Bowman, R.S. Regeneration of surfactant-modified zeolite after saturation with chromate and perchloroethylene. Water Res. 2001, 35, 322-326. [CrossRef]

36. Li, Z.; Anghel, I.; Bowman, R.S. Oxyanion sorption by surfactant-modified zeolite. J. Dispers. Sci. Technol. 1998, 19, 843-857. [CrossRef]

37. Smiljanić, D.; de Gennaro, B.; Izzo, F.; Langella, A.; Daković, A.; Germinario, C.; Rottinghaus, G.E.; Spasojević, M.; Mercurio, M. Removal of emerging contaminants from water by zeolite-rich composites: A first approach aiming at diclofenac and ketoprofen. Microporous Mesoporous Mater. 2020, 298, 110057. [CrossRef]

38. De Gennaro, B.; Fenti, A.; Salvestrini, S. Adsorption of amoxicillin onto organo-modified zeolitic tuff. Adv. Sci. Lett. 2017, 23, 5944-5947. [CrossRef]

39. Chutia, P.; Kato, S.; Kojima, T.; Satokawa, S. Adsorption of As(V) on surfactant-modified natural zeolites. J. Hazard. Mater. 2009, 162, 204-211. [CrossRef]

40. Li, Z.; Beachner, R.; McManama, Z.; Hanlie, H. Sorption of arsenic by surfactant-modified zeolite and kaolinite. Microporous Mesoporous Mater. 2007, 105, 291-297. [CrossRef]

41. Mendoza-Barrón, J.; Jacobo-Azuara, A.; Leyva-Ramos, R.; Berber-Mendoza, M.S.; Guerrero-Coronado, R.M.; Fuentes-Rubio, L.; Martínez-Rosales, J.M. Adsorption of arsenic (V) from a water solution onto a surfactantmodified zeolite. Adsorption 2011, 17, 489-496. [CrossRef]

42. Cappelletti, P.; Colella, A.; Langella, A.; Mercurio, M.; Catalanotti, L.; Monetti, V.; de Gennaro, B. Use of surface modified natural zeolite (SMNZ) in pharmaceutical preparations Part 1. Mineralogical and technological characterization of some industrial zeolite-rich rocks. Microporous Mesoporous Mater. 2017, 250, 232-244. [CrossRef]

43. Caputo, D.; de Gennaro, B.; Aprea, P.; Ferone, C.; Pansini, M.; Colella, C. Data processing of cation exchange equilibria in zeolites: A modified approach. Stud. Surf. Sci. Catal. 2005, 155, 129-140.

44. Hinz, C. Description of sorption data with isotherm equations. Geoderma 2001, 99, 225-243. [CrossRef]

45. Chen, C. Evaluation of Equilibrium Sorption Isotherm Equations. Open Chem. Eng. J. 2013, 7, 24-44. [CrossRef]

46. Lin, J.; Wang, L. Comparison between linear and non-linear forms of pseudo-first-order and pseudo-second-order adsorption kinetic models for the removal of methylene blue by activated carbon. Front. Environ. Sci. Eng. China 2009, 3, 320-324. [CrossRef] 
47. Bowman, R.S. Applications of surfactant-modified zeolites to environmental remediation. Microporous Mesoporous Mater. 2003, 61, 43-56. [CrossRef]

48. De Gennaro, B.; Catalanotti, L.; Cappelletti, P.; Langella, A.; Mercurio, M.; Serri, C.; Biondi, M.; Mayol, L. Surface modified natural zeolite as a carrier for sustained diclofenac release: A preliminary feasibility study. Colloids Surf. B Biointerfaces 2015, 130, 101-109. [CrossRef] [PubMed]

49. Ho, Y.S. Citation review of Lagergren kinetic rate equation on adsorption reactions. Scientometrics 2004, 59, 171-177.

50. Ho, Y.S. Review of second-order models for adsorption systems. J. Hazard. Mater. 2006, 136, 681-689. [CrossRef]

51. Sips, R. Combined form of Langmuir and Freundlich equations. J. Chem. Phys 1948, 16, 490-495. [CrossRef]

52. Toth, J. State Equations of Solid-Gas Interface Layers. Acta Chim. Acad. Sci. Hung. 1971, 69, 311-328.

53. Limousin, G.; Gaudet, J.P.; Charlet, L.; Szenknect, S.; Barthès, V.; Krimissa, M. Sorption isotherms: A review on physical bases, modeling and measurement. Appl. Geochem. 2007, 22, 249-275. [CrossRef]

54. Foo, K.Y.; Hameed, B.H. Insights into the modeling of adsorption isotherm systems. Chem. Eng. J. 2010, 156, 2-10. [CrossRef]

55. Michaels, A.S. Simplified Method of Interpreting Kinetic Data in Fixed-Bed Ion Exchange. Ind. Eng. Chem. 1952, 44, 1922-1930. [CrossRef]

56. Sharififard, H.; Pepe, F.; Aprea, P.; de Gennaro, B. Chemical modification of activated carbon surface with iron functional groups for efficient separation of vanadium: Batch and column study. Res. Chem. Intermed. 2017, 43, 6553-6570. [CrossRef]

57. Leyva-Ramos, R.; Jacobo-Azuara, A.; Diaz-Flores, P.E.; Guerrero-Coronado, R.M.; Mendoza-Barron, J.; Berber-Mendoza, M.S. Adsorption of chromium(VI) from an aqueous solution on a surfactant-modified zeolite. Colloids Surf. A Phys. Eng. Asp. 2008, 330, 35-41. [CrossRef]

(C) 2020 by the authors. Licensee MDPI, Basel, Switzerland. This article is an open access article distributed under the terms and conditions of the Creative Commons Attribution (CC BY) license (http://creativecommons.org/licenses/by/4.0/). 